\title{
The Determinant Factors Affecting the Employee Performance Improvement of Educational Institution, State Institution and State-owned Enterprise
}

\author{
Ana Sriekaningsih ${ }^{1}$, Mariman Darto ${ }^{2}$, Agus Subekti $^{3}$ \\ Lecturer of STIE Bulungan Tarakan, North Kalimantan ${ }^{1}$, Head of PKP2A III \\ Kalimantan', GM Human Capital and General Affair of Pupuk Indonesia Holding \\ Company $^{3}$ \\ an_juf19@yahoo.co.id
}

Keywords :

Competence,

Motivation,

Organizational

Organizational

Religiosity,

Culture,

Citizenship

Behaviors, Performance

\begin{abstract}
This study focuses on the factors that affect the employee performance in terms of institutions where they work. There are three objects or locations that become the research focus, namely educational institutions represented by the state university in East Kalimantan, government institutions represented by the State AdministrationInstitution (LAN) and state-owned institutions represented by PT. Pupuk Kaltim Tbk. The research results show that employee performance is influenced by three factors, namely competence, work motivation, and organizational culture.The performance of government employees is influenced by three factors, namely religiosity, organizational culture, and organizational citizenship behaviors (OCB). And performance of state-owned employees is influenced only by work motivation.
\end{abstract}




\section{INTRODUCTION}

Productivity in terms of quality and quantity achieved by an employee in carrying out his or her job based on the responsibility given to him or her (Mangkunegara, 2011). According to Gibson (2008), the first factor that affect performance is individual variables consisting of abilities and skills, background, and demographics.The second factor affecting performance is psychological variables consisting of perception, attitude, personality, motivation, job satisfaction and job stress. While the third factor affecting performance is an organizational factor consisting of leadership, compensation, conflict, power, organizational structure, job design, organizational culture, and career. According to Robbins (2008), performance is defined as a function of the interaction between ability (A) and motivation (M), which is formulated as performance $=\mathrm{f}(\mathrm{A} \times \mathrm{M})$. The previous theory shows that employee performance is influenced by competence (ability), motivation and organizational culture.In addition, employee performance can also be improved through employee commitment as an intervening variable.According to Kopelman et al. (1990), the factors that affect performance are individual characteristics, organizational charasteristic, and work characteristics. This study focuses on the factors that affect employee performance in terms of institutions where they work. There are three objects or locations that become the research focus, namely educational institutions represented by the state university in East Kalimantan, government institutions represented by the State Administration Institution (LAN) and state-owned institutions represented by PT. Pupuk Kaltim Tbk.

\section{METHOD}

The research design used in this research is explanatory research.Based on the objectives to be achieved, this research can be categorized into empirical research studies taken from the previous research results.

The population in this study is divided into three groups, namely:

1. All lecturers of state universities in East Kalimantan are 972 lecturers and 235 samples are taken.

2. All government employees of the Center ofResearch and Education and Training forGovernment Apparatus I-IV of the State Administration Institution (PKP2A LAN), totaling about 198 people. The number of samples taken are 153 people.

3. All permanent employees at PT Pupuk Kalimantan Timur, Urea fertilizer manufacturer, totaling 2.611 people, with total sample of 140 people.

The sampling technique used a proportional random sample method with purposive sampling approach, where the sample is taken based on the characteristics specified by the researcher. The data used in this research is quantitative data type. Data source in this research is primary data.

\section{RESULTS AND DISCUSSIONS}

Sriekaningsih (2015) conducted a research entitled "The Influence of Competence and Work Motivation and Organizational Culture on Organizational Commitment and Lecturer's Performance at State University in East Kalimantan".The research findings indicate that there are three factors that affect the performance, namely competence, work motivation and organizational culture. The competence has a significant influence on lecturer performance.Lecturer competence is a basic characteristic of a person consisting of knowledge, skill and attitude, which has a causal relationship with outstanding performance or work effectiveness.From the description analysis of lecturer competence variable, the dimension of pedagogic competence, personality, social and professional, show that lecturer competence of state university in East Kalimantan is very high or very good.It means that the lecturers of state university in East Kalimantan have competencies that can support the teaching and learning process to create better graduates.

The variable description of lecturer performance for dimensions work quality, ability, initiative, communication, timeliness, show that the lecturers performance of state university in East Kalimantan is very high or very good. The results of this study support the theory of Spencer and Spencer (1993), that intellectual, emotional and social competence as part of the deepest personality in a person, can predict or influence the effectiveness of individual performance.Theory of Mathis and Jackson (2006) states that individual performance is influenced by the ability, motivation, support received, existence of work performed, and the relationship with the organization. Work motivation also has a significant influence on the performance of lecturers. The higher the work motivation of the lecturers, the higher 
the performance of the lecturers. The descriptions analysis for work motivation variable, for dimensions need for achievement, need for affiliation and need for power, indicate that the motivation of lecturers at state university in East Kalimantan is high or good.The motivation work from lecturers at state university in East Kalimantan to work is quite good. This condition will affect the process of teaching and learning activities on campus.

Organizational culture also has a significant influence on the performance of lecturers.Based on the description analysis of the organizational culture for the dimensions of involvement, consistency, adaptability and mission, it shows that the organizational culture of state university lecturers in East Kalimantan is high or good.Until nowadays, the lecturers have a good organizational culture. This is shown from the commitment of lecturers to remain devoted themselves in the institution where they work. Organizational culture forms the background regarding the environment, working conditions, attitudes, behaviors, and employee perceptions of the organizations in which they work.Behavior is part of a culture that is related to performance, because by behaving, a person will be able to get what is desired and expected.Organizational culture is a powerful mechanism in controlling employee behavior. The results of this study are in line with the theory put forward by Gibson (2008). One of the factors that affect the performance is the organizational factors, which include organizational culture, organizational structure, job design, leadership, reward system. According to Kopelman et al. (1990), the factors that affect the performance are individual characteristics, organizational charasteristic, and work characteristics.Furthermore, Kopelman explained that, in addition to being influenced by environmental factors, performance is also highly dependent on individual characteristics such as ability, knowledge, skills, motivation, norms and values. Darto (2015) conducted a research entitled "The Influence of Transformational Leadership, Religiosity, Job Satisfaction and Organizational Culture to Organizational Citizenship Behavior and Performance of Employees of Center of Research and Education and Training for Government Apparatus of the State Administration Institution".The research findings show that performance is influenced by three factors, namely religiosity, organizational culture, and organizational citizenship behaviors (OCB).

The research results show that there is a significant influence of religiosity on employee performance in the Center of Research and Education and Training for Government Apparatus of the State Administration Institution (LAN).It means that the higher the level of religiosity attached to the employee, the performance of employees is higher as well. From the description analysis, the religiosity variable is considered important by the respondents, and in general, the reality shows that the religiosity of employees in the LAN is good.The most powerful and important factor that forms religiosity is related to the assertion that with religion, the purpose of employee life is more directed. The real conditions of LAN employees indicate that this factor has a very good value.It means that LAN employees have a strong belief in the religion and the religion can be a better way of life. Employee performance is perceived as important by the respondent, and in general, the reality shows that employee performance is perceived good or high by respondent.The most powerful and important factor that forms employee performance isrelated to the employee's willingness to carry out the task in earnest.The reality shows that the performance of employees in the LAN is considered good and high. The results of this study reinforce the theory put forward by Glock and Stark (1965). It states that there are five aspects in religiosity. First, religious belief (the ideological dimension), also called the dimension of belief, is the degree to which a person accepts dogmatic things in his religion, such as belief in God, angels, heaven and hell.Second, religious practice (the ritual dimension) is the degree to which a person undertakes the duties of worship in his religion.Third, the religious feeling (experiental dimension) are feelings that have been experienced, such as feeling close to God, feeling afraid to do sin, feeling that the prayer is granted, being saved by God, and so on.Fourth, the religious knowledge (the intellectual dimension) is a dimension that explains how far one knows about his religious teachings, especially those in scripture and others.Fifth, the religious effect (the consequential dimension), the dimension that measures the extent to which a person's behavior is motivated by his religious teachings in social life. The results of this study also shows that organizational culture has a significant effect on employee performance in LAN.It supports the research results from Moeljono (2005) and Aloku (2003), which state that organizational culture has a positive influence on organizational performance. One of the important stages in organizational change in the State Administration Institution (LAN) is the transformation of organizational culture. The old values that hamper the behavior and performance of the organization need to be stopped or even eliminated, and then transformed into new values that accelerate the organization in achieving its performance. The research results show that organizational citizenship behaviors (OCB) has a significant effect on employee performance in LAN.It means that the higher the organizational citizenship behaviors (OCB) that employees have, the employee performance is higher as well. The description analysis shows that the OCB variable is perceived as important by the respondent. In general, the reality 
indicates that OCB is perceived good by the respondent. The most powerful and important factor that forms the OCB is related to helpful statements and building togetherness in work. The results of this study support the theory of Robbins and Judge (2009). The facts show that organizations that have employees with good OCB will perform better than other organizations.Ahdiyana (2009) indicates that positive behavior of employees or members of the organization through OCB is able to support individual performance and organizational performance for better organizational development.All different types of OCB are valuable to the organization, although OCB are often undetected by the rewards system, but it is evident that individuals who exhibit OCB will have good performance, group and organizational effectiveness. Subekti (2016) conducted a research entitled "Financial Compensation and Assessment System: The Implications for Job Satisfaction and Work Motivation and Employee Performance of PT Pupuk Kalimantan Timur".The research findings show that employee performance is only influenced by work motivation, while financial compensation, employee appraisal system and job satisfaction have no effect on performance. The results showed that the work motivation has a positive and significant effect on employee performance of PT Pupuk Kaltim.It means that the higher the employee motivation, then the employee performance is higher / better.Otherwise, the lower the employee motivation, the employee performance is lower / down. Motivation can certainly affect performance, although it is not the only factor that forms performance.At first, a person's motivation to perform activities arises because he feels the need to meet the needs.Thus, there is a common interest between workers and industry.Workers, on the one hand, do work with expectation of compensation for the fulfillment of their needs. And on the other hand, to achieve their personal goals, to realize their work performance (Umar, 2011). The influence of work motivation on performance, according to Goal Setting Theory put forward by Edwin Locke in Brian Francis Redmond (2015), explains that a person's performance or achievement depends on the person's motivation for the work. The higher a person's motivation to do the job, the higher the level of performance.Conversely, the lower the motivation of a person doing a job, the lower the level of performance. These results are in line with the opinions of Robbins (2003) as well as Mitchell and Larson (1998). Robbins (2003) explained that employee performance is a function of the interaction between ability and motivation.Meanwhile, Mitchell and Larson (1998) created a concept model that explains that motivation affects behavior and work performance.

\section{CONCLUSION AND SUGGESTION}

Based on the results of this study, it can be concluded that the performance of lecturers is influenced by three factors, namely competence, work motivation and organizational culture. The performance of government employees is influenced by three factors, namely religiosity, organizational culture, and organizational citizenship behaviors (OCB).And performance of state-owned employees influenced only by work motivation

\section{REFERENCES}

Ahdiyana, M. 2009. Dimensi OCB dalam Kinerja Organisasi. Yogyakarta: FISE UNY.

Aluko, M. 2003. The Impact of Culture on Organizational Performance in Selected Textile Firms in Nigeria. Nordic Journal of African Studies, Vol. 12. No. 2, 164-179.

Brian Francis Redmond, 2015. Overview of Reinforcement Theory. Work Attitudes and Job Motivation Home-Brian Redmond. Diakses 1 Mei 2015 dari https://wikispaces.psu.edu/display/PSYCH484/3.+Reinforcement + Theory

Darto, Mariman. 2015. Pengaruh Kepemimpinan Transformasional, Religiusitas, Kepuasan Kerja serta Budaya Organisasi terhadap Organizational Citizenship Behavior dan Kinerja Pegawai Pusat Kajian dan Pendidikan dan Pelatihan Aparatur Lembaga Administrasi Negara. Disertasi, Tidak diterbitkan. Program Doktor Fakultas Ekonomi, Universitas Mulawarman, Samarinda.

Gibson, I. 2008. Organisasi. Jakarta: Binarupa Aksara.

Glock, C.andStrak, R. 1965. Religious and Society in Tension. Chicago: Rand Mc Nally.

Kopelman R.E., Brief A.P., Guzzo R.A. 1990. The role of culture and climate in productivity. Dalam:

B. Schneider (ed). Organizational Climate and Culture. Jossey-Bass. San Francisco.

Mangkunegara, A. 2011. Manajemen Sumber Daya Manusia. Bandung: PT. Remaja Rosdakarya

Mathis, R. L and Jackson. J.H. 2006. Manajemen Sumber Daya Manusia, jilid 1. Alih Bahasa: Jimmy Sadeli dan Bayu Prawira. Jakarta: Salemba Empat 
Mitcheel, T.R. and Larson, J.R., Jr. 1987. People in Organizations: An Introduction to Organizational Behavior ( $3^{\text {rd }}$ ed.). New York: McGraw-Hill.

Moeljono, D. 2005. Good Corporate Culture sebagai Inti dari Good Corporate Governance. Jakarta: PT. Elex Media Komputindo.

Robbins, S.P.2003. Organizational Behavior. New Jersey: Prentise Hall . 2008. Perilaku Organisasi. Alih Bahasa: Benyamin Molan. Edisi 9. Jakarta: PT Indeks , and Judge, M. 2009. Organizational Behavior. New Jersey:Prentice Hall Int'1, Inc.

Spencer, L. M., and Spencer, S. M. 1993. Competence at Work: Models for Superior Performance. New York : John Wiley \& Sons, Inc.

Sriekaningsih, Ana. 2015. Pengaruh Kompetensi dan Motivasi Kerja serta Budaya Organisasi terhadap Komitmen Organisasional dan Kinerja Dosen pada Universitas Negeri di Kalimantan Timur.Disertasi, Tidak diterbitkan. Program Doktor Fakultas Ekonomi, Universitas Mulawarman, Samarinda.

Subekti, Agus. 2016. Kompensasi Finansial dan Sistim Penilaian. Implikasinya terhadap Kepuasan Kerja dan Motivasi Kerja serta Kinerja Karyawan PT Pupuk Kalimantan Timur. Disertasi, Tidak diterbitkan. Program Doktor Fakultas Ekonomi, Universitas Mulawarman, Samarinda

Umar Akmal, 2011. Pengaruh Upah, Motivasi Kerja, dan Kepuasan Kerja terhadap Kinerja Pekerja pada Industri Manufaktur di Kota Makassar. Jurnal Aplikasi Manajemen, Vol.10, No.2, Juni. Halaman 406 - 418. ISSN: 1693-5241 